\title{
Enantioselective reduction of acetyldimethylphenylsilane by Trigonopsis variabilis (DSM 70714)
}

\author{
Christoph Syldatk ${ }^{1}$, Hannelore Andree ${ }^{1}$, Andrea Stoffregen ${ }^{1}$, Fritz Wagner ${ }^{1}$, Burghard Stumpf ${ }^{2}$, \\ Ludger Ernst ${ }^{2}$, Harald Zilch ${ }^{3}$, and Reinhold Tacke ${ }^{3}$ \\ 1 Institute of Biochemistry and Biotechnology, Technical University of Braunschweig, \\ Bültenweg 17, D-3300 Braunschweig, Federal Republic of Germany \\ 2 Gesellschaft für Biotechnologische Forschung mbH (GBF), \\ Mascheroder Weg 1, D-3300 Braunschweig, Federal Republic of Germany \\ 3 Institute of Inorganic and Analytical Chemistry, Technical University of Braunschweig, \\ Hagenring 30, D-3300 Braunschweig, Federal Republic of Germany
}

\begin{abstract}
Summary. Growing and resting cells of the yeast Trigonopsis variabilis (DSM 70714) can be used for the enantioselective reduction of the organosilicon compound acetyldimethylphenylsilane (I) to give optically active $(R)$-(1-hydroxyethyl)dimethylphenylsilane $[(R)-2]$ in good yields. The enantiomeric purity of the isolated product was determined to be $62-86 \%$ ee depending on the substrate concentration used. Both substrate and product caused an inhibition of the reaction at concentrations higher than 0.35 and $0.5 \mathrm{~g} / 1$, respectively. Besides, higher substrate and product concentrations led to increased formation of the by-product 1,1,3,3-tetramethyl-1,3-diphenyldisiloxane. Considering the limiting substrate and product concentrations, it was possible to use the same biomass at least 5 times without significant loss of enzyme activity. 3-Methyl-3-phenyl-2-butanone (5) and acetyldimethylphenylgermane (7), which represent carbon and germanium analogues of 1 , were also found to be accepted as substrates by Trigonopsis variabilis (DSM 70714). The reduction rates of the silicon $(l)$ and germanium compound ( 7 ) were much higher than the transformation rate of the corresponding carbon analogue 5 .
\end{abstract}

\section{Introduction}

The great efficiency of biotransformation steps in asymmetric organic synthesis has been sufficiently appreciated in numerous reviews (e.g. Leuenberger 1984; Leuenberger and Kieslich 1984; Sih and Chen 1984; Schmidt-Kastner and Egerer 1984; Sariaslani and Rosazza 1984; White-

Offprint requests to: C. Syldatk or R. Tacke sides and Wong 1985). There are many examples of compounds accessible by bioconversions, which are not available so far by chemical methods (resolution of racemates via diastereomeric derivatives, asymmetric chemical synthesis, stereospecific reactions) at all or only at much higher costs (Sih and Rosazza 1976; Jones 1985). One important application of biotransformations is the preparation of optically active compounds for the use as drugs, agrochemicals or as feed and food stuffs (Rétey and Robinson 1982).

In recent years there has been increasing interest in optically active organosilicon compounds with respect to their use as reagents in asymmetric organic synthesis (Larson and Torres 1985) and as drugs in experimental pharmacology (Sheldrick et al. 1985; Tacke and Zilch 1986a, b). Several methods have been employed to prepare optically active silicon compounds including resolution through separation of diastereomers, kinetic resolution, asymmetric synthesis, as well as stereospecific reactions starting from resolved compounds (Corriu and Guérin 1982; Corriu et al. 1984). Recently, it was shown for the first time that biotransformations are also useful for preparing optically active organosilicon compounds: Some microorganisms were found to reduce carbonyl groups of various organosilicon substrates stereoselectively to give the corresponding optically active alcohols (Tacke et al. 1983; Tacke et al. 1984; Tacke et al. 1985; Tacke and Zilch 1986a; Syldatk et al. 1986). One of these bioconversions is the enantioselective reduction of acetyldimethylphenylsilane $(I)$ to give $(R)$-(1-hydroxyethyl)dimethylphenylsilane [ $(R)-2]$. The aim of the present work was to optimize this biotransformation process and to develop reproducible procedures to obtain $(R)-2$ in high yield and with high enantiomeric purity at low costs. It was of interest to find 
out, which sideconditions have to be fulfilled for a complete and highly enantioselective reduction of 1 and which influence 1 and $(R)-2$ have on the microorganisms.

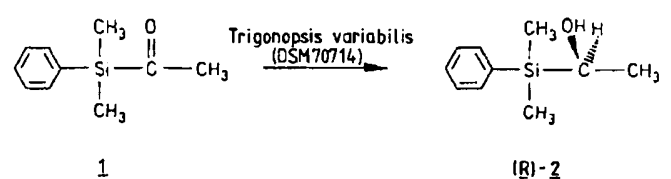

\section{Materials and methods}

Microorganisms. One hundred yeasts were tested for their ability to reduce the substrate acetyldimethylphenylsilane $(I)$ to give the corresponding alcohol (1-hydroxyethyl)dimethylphenylsilane (2). All microorganisms were obtained from public type culture collections (ATCC, CBS, DSM).

Medium and culture conditions. The microorganisms were cultivated under aerobic conditions at $\mathrm{pH} 6.8$ and $27^{\circ} \mathrm{C}$ in a medium containing $0.5 \%$ yeast extract, $2 \%$ malt extract, $1 \%$ peptone and $2.5 \%$ glucose.

Screening experiments were carried out in shaking flasks $(100 \mathrm{ml})$ containing $20 \mathrm{ml}$ of medium. The microorganisms were incubated at $100 \mathrm{rpm}$ for $24-48 \mathrm{~h}$ before $20-50 \mathrm{mg}$ of substrate 1 were added to the growing cells. For a preparative scale, the selected microorganism was cultivated in shaking flasks $(2000 \mathrm{ml})$ containing $500 \mathrm{ml}$ of medium in the same way before adding the neat substrate to the culture broth $(\rightarrow$ substrate concentration $0.2-0.5 \mathrm{~g} / \mathrm{l}$ ). Batch cultivations were carried out in a $G 20$ bioreactor (Braun-Melsungen AG, Melsungen, FRG) equipped with flat blades. Physiological activity of the cells was monitored using a $\mathrm{pH}$-electrode, a $\mathrm{pO}_{2}$-electrode, as well as oxygen and carbon dioxide analyzers (Maihak, Hamburg, FRG). During the cultivations a constant $\mathrm{pH}$ value of $\mathrm{pH} 6.8$ was maintained by titration with a $10 \%$ aqueous solution of $\mathrm{NaOH}$. The time course of the cultivations was followed by measuring the yeast dry mass and the glucose concentration. Cells for the resting cell experiments were harvested by centrifugation at $20000 \mathrm{rpm}$ with a Padberg centrifuge type 41 (Carl Padberg GmbH, Lahr, FRG) after the Csource had been consumed.

Synthesis of substrate 1 and its racemic reduction product rac-2: Acetyldimethylphenylsilane ( $I$ ) was synthesized as described in the literature (Zilch and Tacke 1986c).

rac-(1-Hydroxyethyl)dimethylphenylsilane (rac-2): A solution of $10 \mathrm{mmol} 1 \mathrm{in} 10 \mathrm{ml}$ of dry ether was added dropwise to a stirred slurry of $20 \mathrm{mmol} \mathrm{LiAlH}_{4}$ in $50 \mathrm{ml}$ ether during $10 \mathrm{~min}$ at room temperature. After stirring at room temperature for $1 \mathrm{~h}$, the mixture was cooled and poured into $50 \mathrm{ml}$ of $6 \mathrm{~N}$ aqueous $\mathrm{HCl}$ at $0^{\circ} \mathrm{C}$. The organic layer was separated, washed with dilute aqueous $\mathrm{NaHCO}_{3}$, and dried over anhydrous $\mathrm{Na}_{2} \mathrm{SO}_{4}$. The solvent was evaporated under reduced pressure and the residue purified by Kugelrohr distillation $\left(70^{\circ} \mathrm{C}, 0.1\right.$ Torr) and column chromatography [silica gel 60 (Merck AG, Darmstadt, FRG), ether/n-hexane $1: 1.5(\mathrm{~V} / \mathrm{V})]$ to give a colourless liquid (yield $90 \%$ ). 'H-NMR $\left(\mathrm{CDCl}_{3}\right.$; WM 400-spectrometer, Bruker): $\delta=0.32\left(\mathrm{~s}, 6 \mathrm{H}, \mathrm{SiCH}_{3}\right), 1.25(\mathrm{~d}, J=7.6 \mathrm{~Hz}$, $\left.3 \mathrm{H}, \mathrm{CCH}_{3}\right), 3.66\left(\mathrm{q}, J=7.6 \mathrm{~Hz}, 1 \mathrm{H}, \mathrm{SiCH}(\mathrm{OH}) \mathrm{CH}_{3}\right), 7.1-7.7$ (m, $5 \mathrm{H}, \mathrm{SiC}_{6} \mathrm{H}_{5}$ ), $\mathrm{OH}$ not located. MS (70 eV; $\mathrm{CH} 7$-spectrometer, Varian MAT): $\mathrm{m} / \mathrm{z}=165\left(44 \%, \mathrm{M}^{+}-\mathrm{CH}_{3}\right), 135(100 \%$, $\left.\mathrm{M}^{+}-\mathrm{CH}(\mathrm{OH}) \mathrm{CH}_{3}\right)$. Anal. $\left(\mathrm{C}_{10} \mathrm{H}_{16} \mathrm{OSi}\right) \mathrm{C}, \mathrm{H}$.

Biotransformations. Biotransformations of the substrate acetyldimethylphenylsilane (l) by growing cells of the yeast Trigonopsis variabilis (DSM 70714) were carried out in a bioreactor by adding the neat compound to the culture medium under sterile conditions in three portions 16,28 and $29 \mathrm{~h}$ after start of the cultivation (see Fig. 1 B); the respective substrate concentrations were $0.5 \mathrm{~g} / 1$. Experiments with resting cells were carried out under various conditions in $250 \mathrm{ml}$ shaking flasks containing $50 \mathrm{ml}$ of $0.1 \mathrm{M}$ Sörensen phosphate buffer, $1.0 \%$ glucose, $25.0 \mathrm{~g}$ yeast wet mass, and various concentrations of acetyldimethylphenylsilane (I). The yeast wet mass was washed twice with $0.1 \mathrm{M}$ Sörensen phosphate buffer ( $\mathrm{pH}$ 6.8) before use.

Analytical procedure. After various times of incubation, $1 \mathrm{ml}$ of the culture suspension was extracted with $n$-hexane or ethyl acetate. Qualitative detection of substrate 1 and product 2 was performed by thin layer chromatography on silica gel plates (No. 5554, Merck AG, Darmstadt, FRG) with ether/n-hexane [1:1.5 (V/V)]. 1 and 2 were detected by spraying the plates with 4-methoxybenzaldehyde (Krebs et al. 1967). Quantitative determinations of 1 and 2 were carried out by gas chromatography using a Packard gas chromatograph model 428: Column OV17 $(500 \mathrm{~mm})$, isothermal mode at $100^{\circ} \mathrm{C}$.

Preparative isolation and purification of the biotransformation product $(R)-2$. The whole culture broth was extracted twice with ethyl acetate. After removing the solvent with a rotary evaporator, the crude product was purified by column chromatography on silica gel 60 (Merck AG, Darmstadt, FRG) with ether/n-hexane [1:1.5 (V/V)] as the eluent, followed by Kugelrohr distillation in vacuo. Purification by preparative layer chromatography on silica gel plates (No. 5745, Merck AG, Darmstadt, FRG) was also successful. The spectroscopic properties of the purified product were identical with those of rac-2, which was obtained by chemical synthesis (see above).

Enantiomeric purity and absolute configuration of $(R)-2$. The enantiomeric purities of the biotransformation products were determined by ' $H$-NMR measurements after derivatisation with $(+)-\alpha$-methoxy- $\alpha$-trifluoromethylphenylacetyl chloride according to Mosher's method (Dale et al. 1969). These determinations were performed with the purified biotransformation products (after chromatography and distillation). The absolute configuration of the excess enantiomer was determined by a 'H-NMR correlation method described in the literature (Dale and Mosher 1973). The specific rotation of pure $(R)-2(100 \%$ ee) was calculated to be $[\alpha]_{546}=+24^{\circ}\left(\mathrm{c}=1, \mathrm{CHCl}_{3}\right)$. This value was obtained by extrapolation from the optical rotations of different samples with known enantiomeric purities as determined by Mosher's method.

\section{Results}

\section{Screening experiments}

One hundred yeasts were tested for their ability to transform acetyldimethylphenylsilane (1) into $(R)$-(1-hydroxyethyl)dimethylphenylsilane [(R)-2]. The racemic reduction product rac-2, which was prepared by chemical synthesis as described 
above, was used as reference in these experiments. Most of the yeasts were able to reduce 1 Trigonopsis variabilis (DSM 70714) showed the best results concerning the reaction rate, the isolation and the purity of the product 2 with respect to the formation of biogenic by-products, and was therefore used in the experiments described in this paper.

\section{Biotransformation by growing cells}

Figure 1 shows the time course of the cultivation of Trigonopsis variabilis (DSM 70714) in a bio-
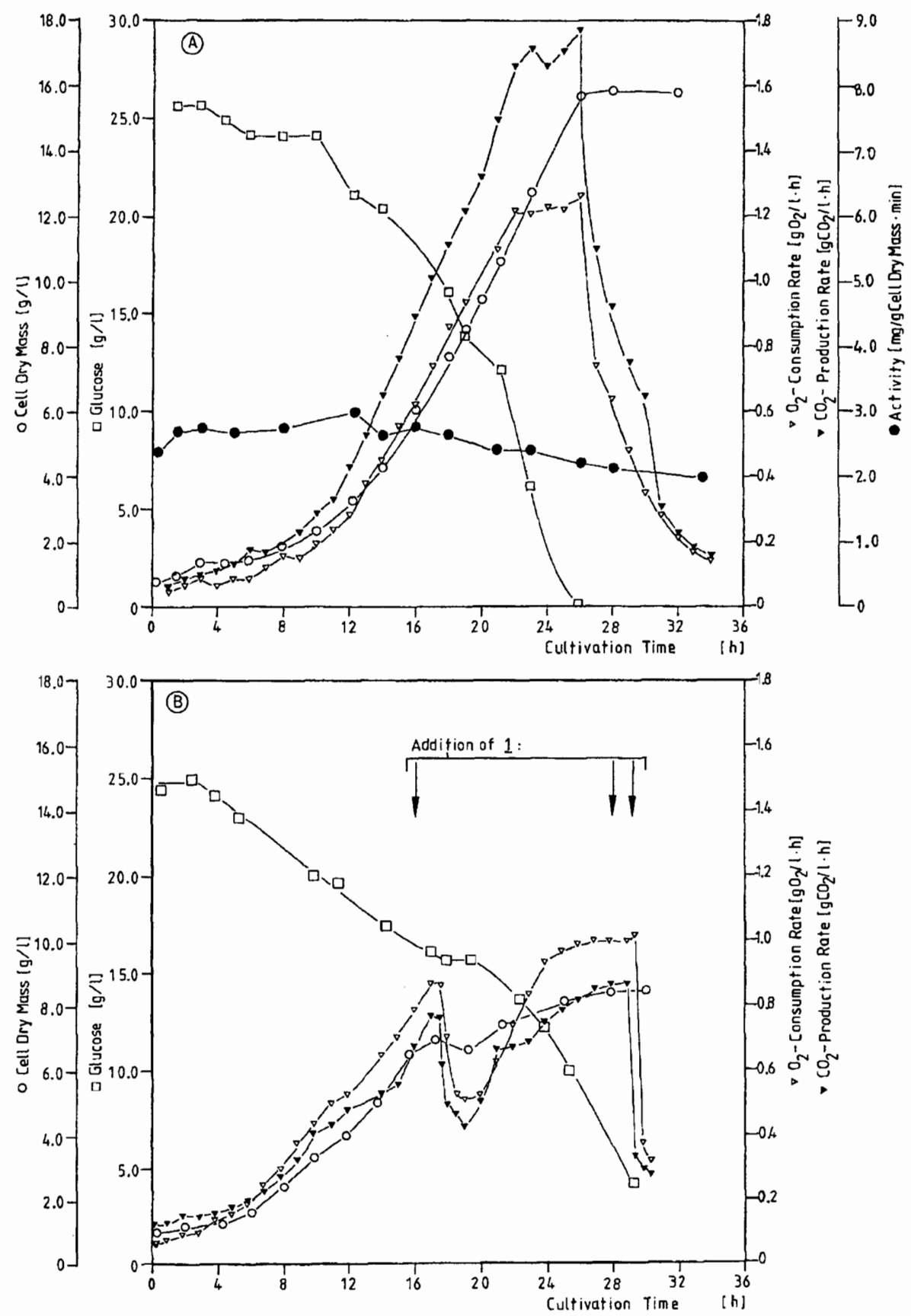

Fig. 1. Time course of the cultivation of Trigonopsis variabilis (DSM 70714) in a $20 \mathrm{l}$ bioreactor without addition of acetyldimethylphenylsilane $(I)(A)$ and with addition of three portions of $0.5 \mathrm{~g} / 11$ (neat compound) 16,28 and $29 \mathrm{~h}$ after the start of the cultivation (B) (conditions: medium containing $0.5 \%$ yeast extract, $2 \%$ malt extract, $1 \%$ peptone, and $2.5 \%$ glucose; $\mathrm{pH} 6.8,27^{\circ} \mathrm{C}$ $400 \mathrm{rpm}, 0.5 \mathrm{~V} / \mathrm{V} \mathrm{min})$ 
reactor without addition of 1 (Fig. 1A) and with addition of $0.5 \mathrm{~g} / \mathrm{l}$ of neat 116,28 and $29 \mathrm{~h}$ after the start of the growth (Fig. 1B). The addition of the substrate had an inhibiting effect on the $\mathrm{O}_{2}$ consumption and on the growth of the microorganism. While the first biotransformation with growing cells was complete after only $20 \mathrm{~min}$ (see Fig. 2), a second transformation took $60 \mathrm{~min}$. The third one, following $1 \mathrm{~h}$ after the second bioconversion, required even $4 \mathrm{~h}$. The crude product, obtained by extraction of the culture broth, was found to contain many biogenic by-products. After purification the biotransformation product $(R)-2$ could be isolated with a yield of $54 \%$ and an enantiomeric purity of $84 \%$ ee.

\section{Biotransformation by resting cells}

Figure 1A shows the growth of Trigonopsis variabilis (DSM 70714) without addition of 1 . At several points of time samples were taken to test the enzymatic activity of the cells as a function of their physiological age under resting cell conditions. Since there was no difference in the enzymatic activity of cells from different growth phases, biomass from the late exponential phase of growth was used for the following experiments. Figure 3 shows the biotransformation of 1 by growing cells in a bioreactor in comparison with the bioconversion by resting cells in a phosphate buffer containing only $1 \%$ glucose for the co-enzyme regeneration. Since only a slight difference in specific activity was observed, resting cell experiments were used to optimize the reaction con-

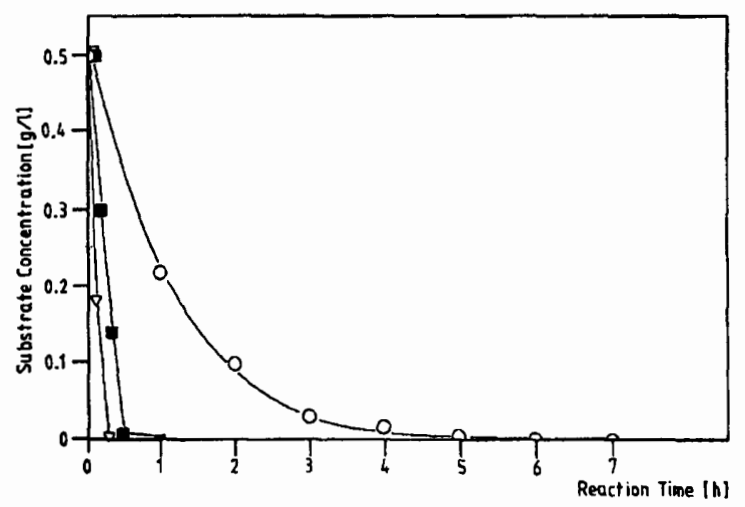

Fig. 2. Time course of the reduction of acetyldimethylphenylsilane (1) by growing cells of Trigonopsis variabilis (DSM 70714). The neat substrate was added in three portions to the culture broth (respective substrate concentration $0.5 \mathrm{~g} / \mathrm{l}$ ) 16 $(\nabla), 28(\square)$ and $29 \mathrm{~h}(O)$ after the start of the cultivation (conditions: see Fig. 1)

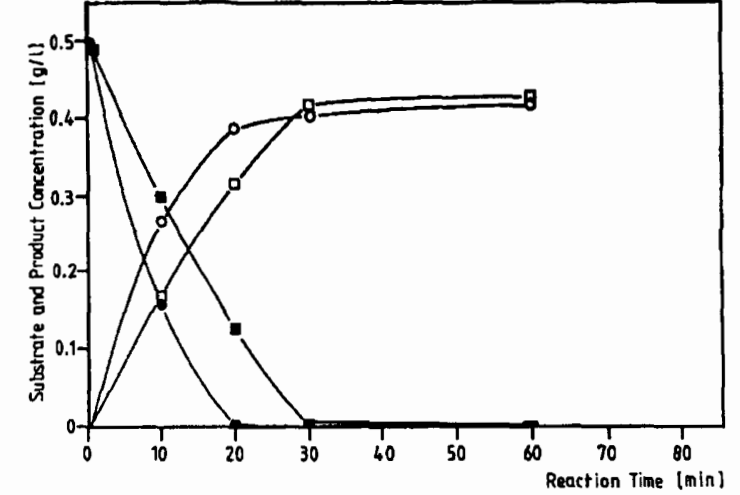

Fig. 3. Time course of the reduction of acetyldimethylphenylsilane (1) (closed symbols) and the formation of (1-hydroxyethyl)dimethylphenylsilane (2) (open symbols) by growing (O) and resting cells ( $\square$ ) of Trigonopsis variabilis (DSM 70714) (reaction conditions: substrate concentration $0.5 \mathrm{~g} / 1,25.0 \mathrm{~g} / \mathrm{l}$ yeast wet mass, $500 \mathrm{ml}$ shaking flasks containing $100 \mathrm{ml}$ medium; conditions for growing cells: $0.5 \%$ yeast extract, $2 \%$ malt extract, $1 \%$ peptone, and $2.5 \%$ glucose; $\mathrm{pH} 6.8,27^{\circ} \mathrm{C}, 100$ rpm; conditions for resting cells: Sörensen phosphate buffer, $\mathrm{pH} 6.8,27^{\circ} \mathrm{C}, 1 \%$ glucose, $100 \mathrm{rpm}$ )

ditions. With regard to the transformation rate of 1 , a temperature of $37^{\circ} \mathrm{C}$ and a $\mathrm{pH}$ value in the range of $6.0-8.0$ were found to be optimal conditions. A linear correlation was observed between the biomass concentration and the reaction rate. In addition, the glucose concentration was found to play an important role: For the complete reduction (gaschromatographic control) of $0.5 \mathrm{~g} / 1$ substrate $3 \mathrm{~g} / 1$ glucose had to be added per gram cell dry mass per liter.

In experiments with varying substrate concentrations, $l$ was found to have an inhibiting effect on the enzymatic activity of the cells at substrate concentrations higher than $0.35 \mathrm{~g} / 1$ (see Fig. 4).

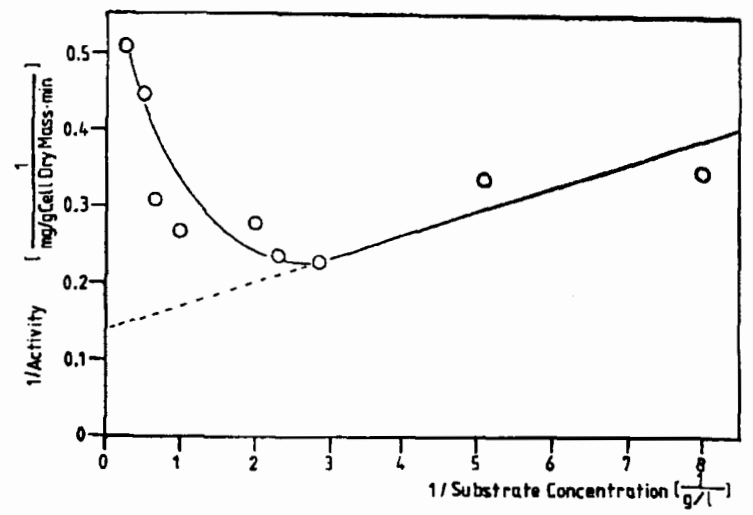

Fig. 4. Lineweaver Burk plot of the substrate concentration against the specific reduction activity $(1 \rightarrow 2)$ of resting cells of Trigonopsis variabilis (DSM 70714) 


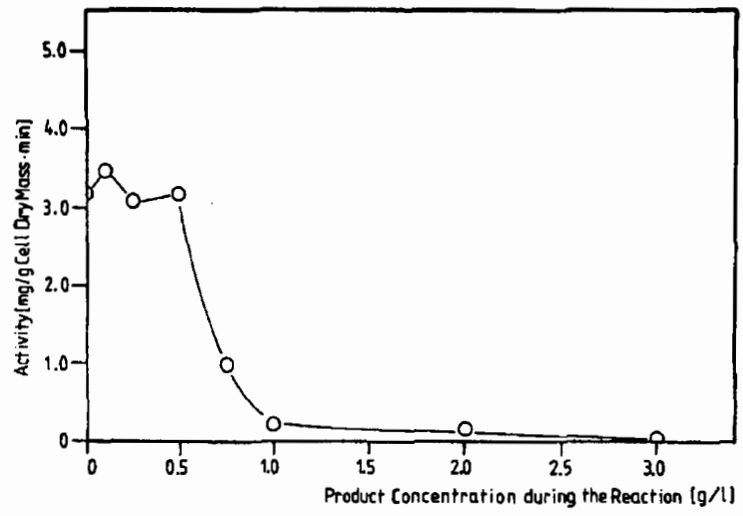

Fig. 5. Dependence of the specific reduction activity $(1 \rightarrow 2)$ of resting cells of Trigonopsis variabilis (DSM 70714) on the product concentration (reaction conditions: Sorrensen phosphate buffer, $\mathrm{pH} 6.8,27^{\circ} \mathrm{C}, 1 \%$ glucose, $25 \mathrm{~g} / 1$ yeast wet mass)

This effect, which had already been indicated by the growing cell experiments in the bioreactor (see Figs. 1B and 2), is irreversible and nearly complete at substrate concentrations higher than $1 \mathrm{~g} / \mathrm{l}$. Product concentrations higher than $0.5 \mathrm{~g} / \mathrm{l}$ also caused inhibition (see Fig. 5).

At substrate concentrations of $1.0 \mathrm{~g} / \mathrm{l}$ or higher, not only the reaction velocity dropped rapidly, but also the by-product 1,1,3,3-tetramethyl-1,3-diphenyldisiloxane (4) could be monitored by gas chromatography (by comparison with an authentic sample) and isolated from the reaction mixture. The disiloxane 4 is a condensation product of dimethylphenylsilanol (3), the formation of which may be explained by a cleavage of the $\mathrm{Si}-\mathrm{C}$ bond of the $\mathrm{Si}-\mathrm{C}(\mathrm{O}) \mathrm{CH}_{3}$ unit of 1 . Even after incubating 1 with heat-treated cells ( $\rightarrow$ inactivation of the enzymes by heating the cells for $90 \mathrm{~min}$ at $60^{\circ} \mathrm{C}$ ), the disiloxane 4 could be isolated indicating that its formation is probably not an enzymatic but rather a chemical one.<smiles>CS(C)(O)c1ccccc1</smiles>

3

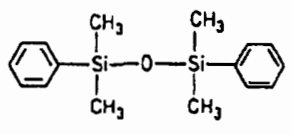

4
Considering the inhibiting substrate and product concentrations, it was possible to use free resting cells at least five times for the reduction of 1 without significant loss of activity, if they were separated from the reaction mixture by centrifugation and washed with phosphate buffer before the next biotransformation. Moreover, it was pos- sible to store the cells by freezing at $-32^{\circ} \mathrm{C}$ without significant inactivation.

As can be seen from Table 1 , the substrate concentration was found to play an important role for the enantioselectivity of the biotransformation. Enantiomeric purities between 62 (substrate concentration $1.0 \mathrm{~g} / \mathrm{l}$ ) and $86 \%$ ee (substrate concentration $0.25 \mathrm{~g} / \mathrm{l}$ ) were observed; the enantiomeric purity increased with decreasing substrate concentration.

The crude product isolated from the reaction mixture of the resting cells by extraction with ethyl acetate contained much less biogenic byproducts than in the case of growing cells; isolation and purification were much easier. Using a substrate concentration of $0.25 \mathrm{~g} / \mathrm{l},(R)-2$ was obtained in a yield of $70 \%$ and an enantiomeric purity of $86 \%$ ee.

Preliminary studies have shown that 3-methyl3-phenyl-2-butanone (5) and acetyldimethylphenylgermane ( 7$)$ are also accepted as substrates by Trigonopsis variabilis (DSM 70714) to give the reduction products 6 (not isolated; structural proof by gaschromatographic comparison with an authentic racemic sample of $\sigma$ ) and 8 (isolated as the $(R)$-configurated enantiomer; structural proof by elemental analysis and spectroscopic investigations). Compounds 5 and 7 represent a carbon and a germanium analogue, respectively, of ace-

Table 1. Dependence of the enantiomeric purity [enantiomeric excess (\% ee)] of the reduction product $(R)-2$ on the concentration of the substrate acetyldimethylphenylsilane (I) (reaction conditions: $0.1 \mathrm{M}$ Sorrensen phosphate buffer, $\mathrm{pH} 6.8,27^{\circ} \mathrm{C}$, $2.5 \%$ glucose, $25.0 \mathrm{~g} / 1$ yeast wet mass)

\begin{tabular}{ll}
\hline $\begin{array}{l}\text { Substrate concentration } \\
{[\mathrm{g} / \mathrm{l}]}\end{array}$ & $\begin{array}{l}\text { Enantiomeric excess of } \\
(R)-2[\% \mathrm{ee}]\end{array}$ \\
\hline 1.0 & 62 \\
0.5 & 68 \\
0.35 & 77 \\
0.25 & 86 \\
\hline
\end{tabular}

Table 2. Specific activities of resting cells of Trigonopsis variabilis (DSM 70714) concerning the transformation of acetyldimethylphenylsilane ( 1 ) and its carbon (5) and germanium analogue (7). The substrates were added as neat compounds (reaction conditions: $0.1 \mathrm{M}$ Sörensen phosphate buffer, $\mathrm{pH} 6.8$, $27^{\circ} \mathrm{C}, 2.5 \%$ glucose, $25.0 \mathrm{~g} / 1$ yeast wet mass, substrate concentration $0.35 \mathrm{~g} / \mathrm{l}$ )

\begin{tabular}{lll}
\hline Substrate & El & Activity $[\mathrm{mg} / \mathrm{g}$ cell dry mass $\cdot \min ]$ \\
\hline 1 & Si & 4.2 \\
5 & C & 0.2 \\
7 & Ge & 2.4 \\
\hline
\end{tabular}


tyldimethylphenylsilane (1). As can be seen from Table 2, the highest specific activity of the yeast was observed in the case of the silicon compound 1 , and the lowest specific activity for the carbon analogue 5 . These investigations were carried out with resting cells using substrate concentrations of $0.35 \mathrm{~g} / \mathrm{l}$. Systematic studies of the biotransformations $5 \rightarrow 6$ and $7 \rightarrow 8$ are in progress.

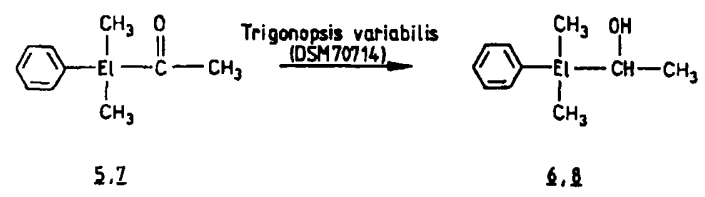

\section{Discussion}

The results presented in this paper demonstrate that biotransformations can be used for the preparation of optically active organosilicon compounds. By analogy to the enantioselective reduction of many organic ketones $\left(\mathrm{R}_{3} \mathrm{C}-\mathrm{CO}-\mathrm{CR}_{3}\right)$ by various yeast species, acetyldimethylphenylsilane (1) with its $\mathrm{R}_{3} \mathrm{C}-\mathrm{CO}-\mathrm{SiR}_{3}$ unit is transformed by Trigonopsis variabilis (DSM 70714) into the reduction product $(R)-2$. Although a carbonyl group attached to silicon differs substantially in its properties from a carbonyl unit bound to carbon (Brook 1968; Armitage 1982), the CO group of 1 is accepted by the microorganism in a "normal manner".

The growth of Trigonopsis variabilis (DSM 70714 ) is inhibited by the addition of 1 to the culture medium at a concentration of $0.5 \mathrm{~g} / 1$ as one can see from Fig. 1. The experiments with resting cells and varying substrate concentrations showed that 1 and 2 also have an inhibiting effect on the enzymatic reduction activity of the yeast at concentrations higher than 0.35 and $0.5 \mathrm{~g} / \mathrm{l}$. Using substrate concentrations of 1 of $1.0 \mathrm{~g} / \mathrm{l}$ or higher, the by-product 1,1,3,3-tetramethyl-1,3-diphenyldisiloxane (4) is produced. The enantiomeric purity of the product 2 also depends on the substrate concentration used. The highest ee values were obtained at low substrate concentrations. Such dependence of enantiomeric purity on substrate concentration has already been reported in the literature for related reductions (Matzinger and Leuenberger 1985; Sih and Chen 1984; Sih et al. 1984).

There is probably more than one enzyme in Trigonopsis variabilis (DSM 70714) involved in the reduction of 1 , which are characterized by different $\mathrm{K}_{\mathrm{M}}$-values and stereoselectivities as is the case in the reduction of $\beta$-ketoesters by Saccharomyces cerevisiae (Sih et al. 1984).

Considering these results and the fact, that resting cells can be reused five times without significant loss of activity for the reduction of 1 , these experiments seem to be an appropriate basis for a continuous process with immobilized resting cells. Such a process with low substrate and product concentrations could be more advantageous than a batch process with respect to the enantioselectivity of the biotransformation. The use of immobilized resting cells seems to be interesting for the reduction of acetyldimethylphenylsilane (1) and structurally related silicon and germanium compounds on a preparative scale, because immobilized cells often show greater stability than resting free cells and can be reused to catalyze enzymatic reactions for several weeks without significant loss of activity; however, the reaction speed is often reduced as compared with resting free cells (Klein and Wagner 1986; Chibata et al. 1983). It might therefore be interesting to investigate the effect of immobilization on the reaction velocity of the bioconversion $1 \rightarrow(R)-2$, on the stability of the biocatalyst, as well as on the yield and enantiomeric purity of the biotransformation product in comparison with the results obtained with free resting cells. Concerning the preparative aspects of this biotransformation, positive results with immobilized cells would represent a greater efficiency of the process because the separation of the cells from the reaction mixture and the isolation and purification of the product is, in general, much easier than with processes that use growing or free resting cells, respectively. We will soon report on the results of these experiments.

Furthermore, we are investigating the microbial reduction of other acetyltriorganylsilanes $\mathrm{R}^{1} \mathrm{R}^{2} \mathrm{R}^{3} \mathrm{Si}(\mathrm{CO}) \mathrm{CH}_{3}$ and acetyltriorganylgermanes $R^{1} R^{2} R^{3} \mathrm{Ge}(\mathrm{CO}) \mathrm{CH}_{3} \quad\left(\mathrm{R}^{1}=\mathrm{R}^{2} \neq \mathrm{R}^{3}, \mathrm{R}^{1} \neq \mathrm{R}^{2} \neq \mathrm{R}^{3}\right)$ at the moment, which are structurally related to 1 and 7 , respectively (Tacke et al. 1985), to learn about the influence of the substituents attached to silicon and germanium on reaction speed and stereoselectivity. It is of interest to see whether the stereochemistry of these biotransformations is in agreement with Prelog's rule (Prelog 1964). Furthermore, we are studying other microbial and enzymatic reaction types with regard to their applicability on elementorganic substrates, such as esterase (Syldatk et al. 1986) and amidase reactions, which have been described to reveal wide substrate specifity (e.g.: Whitesides and Wong 1985; 
Kasai et al. 1984; Schmidt-Kastner and Egerer 1984); Yonaha and Soda 1986).

Acknowledgements. R. Tacke acknowledges the support of this work by the Land Niedersachsen, the Fonds der Chemischen Industrie, and the Bayer $A G$ (Leverkusen and Elberfeld).

\section{References}

Armitage DA (1982) Organosilanes. In: G Wilkinson, FGA Stone, EW Abel (eds) Comprehensive organometallic chemistry, vol 2. Pergamon Press, Oxford/New York/ Toronto/Sydney/Paris/Frankfurt, pp 1-203

- Brook AG (1968) Keto derivatives of group IV organometalloides. Adv Organomet Chem 7:95-155

Chibata I, Tosa T, Fujimura M (1983) Immobilized living microbial cells. Ann Rep Ferm Proc 6:1-22

Corriu RJP, Guérin C (1982) Nucleophilic displacement at silicon: Recent developments and mechanistic implications. Adv Organomet Chem 20:265-312

Corriu RJP, Guérin C, Moreau JJE (1984) Stereochemistry at silicon. Topics Stereochem 15:43-198

Dale JA, Dull DL, Mosher HS (1969) $\alpha$-Methoxy- $\alpha$-trifluoromethylphenylacetic acid, a versatile reagent for the determination of enantiomeric composition of alcohols and amines. J Org Chem 34:2543-2549

Dale JA, Mosher HS (1973) Nuclear magnetic resonance enantiomer reagents. Configurational correlations via nuclear magnetic resonance chemical shifts of diastereomeric mandelate, $O$-methylmandelate, and $\alpha$-methoxy- $\alpha$-trifluoromethylphenylacetate (MTPA) esters. J Am Chem Soc 95:512-519

Jones JB (1985) An illustrative example of a synthetically useful enzyme: Horse liver alcohol dehydrogenase. In: Ciba Foundation Symposium 111 (ed) Enzymes in organic synthesis. Pitman, London, pp 3-21

Kasai M, Kawai K, Imuta M, Ziffer H (1984) Enantioselective ester hydrolyses employing Rhizopus nigricans. A method of preparing and assigning the absolute stereochemistry of cyclic alcohols. J Org Chem 49:675-679

Klein J, Wagner F (1986) Different strategies to optimize the production phase of immobilized cells. In: Enzyme Engineering VIII (in press)

Krebs KG, Heusser D, Wimmer H (1967) Sprühreagenzien. In: E Stahl (ed) Dünnschichtchromatographie. Springer, Berlin - Heidelberg - New York, pp 813-859

Larson GL, Torres E (1985) Asymmetric induction by chiral silicon groups. J Organomet Chem 293:19-27

Leuenberger HGW (1984) Methodology. In: H-J Rehm, G Reed (eds) Biotechnology, vol 6a. Biotransformations. Verlag Chemie, Weinheim, pp 5-29

Leuenberger HGW, Kieslich K (1984) Biotransformationen. In: P Präve, U Faust, W Sittig, DA Sukatsch (eds) Handbuch der Biotechnologie. Verlag Oldenbourg, München/ Wien, pp 454-482

Matzinger PK, Leuenberger HGW (1985) Screening for microorganisms performing the stereoselective reduction of $\alpha$ formyl-esters. Appl Microbiol Biotechnol 22:208-210

Prelog V (1964) Specification of the stereospecifity of some oxido-reductases by diamond lattice sections. Pure Appl Chem 9:119-130

Rétey J, Robinson JA (1982) Stereospecificity in organic chemistry and enzymology. In: HF Ebel (ed) Monographs in modern chemistry, vol 13. Verlag Chemie, Weinheim/ Deerfield Beach/Basel
Sariaslani FS, Rosazza JPN (1984) Biocatalysis in natural product chemistry. Enzyme Microb Technol 6:242-253

Schmidt-Kastner G, Egerer P (1984) Amino acids and peptides. In: HJ Rehm, G Reed (eds) Biotechnology vol 6a Biotransformations. Verlag Chemie, Weinheim, pp 387-419 Sheldrick WS, Linoh $H$, Tacke R, Lambrecht $G$, Moser U, Mutschler E (1985) Sila-pharmaca. Part 32. Crystal and molecular structures of the $(R)$-enantiomer and the racemate of the antimuscarinic agent (cyclohexyl)phenyl[2(pyrrolidin-1-yl)ethyl]silanol (sila-procyclidine). J Chem Soc Dalton Trans 1985:1743-1746

Sih CJ, Chen C-S (1984) Microbial asymmetric catalysis. Enantioselective reductions of ketones. Angew Chem Int Ed Engl 23:570-578

Sih CJ, Rosazza JP (1976) Microbial transformations in organic synthesis. In: B Jones, CH Sih, D Perlman (eds) Techniques of chemistry X: Applications of biochemical systems in organic chemistry. John Wiley and Sons, New York, pp 69-106

Sih CJ, Zhou B-N, Gopalan AS, Shieh W-R, Chen C-S, Girdaukas G, Vanmiddlesworth $F$ (1984) Enantioselective reductions of $\beta$-keto esters by Baker's yeast. In: AJ Laskin (ed) Enzyme Engineering 7, Ann New York Acad Sc 434, New York, pp 186-193

Syldatk C, Andree H, Wagner F, Wuttke F, Zilch H, Tacke R (1986) Einsatz von Biokatalysatoren zur Herstellung optisch aktiver elementorganischer Verbindungen. 4. DECHEMA-Jahrestagung der Biotechnologen, Frankfurt/ Main 1986, Abstracts, pp 171-172

Tacke R, Linoh H, Stumpf B, Abraham W-R, Kieslich K, Ernst L (1983) Mikrobiologische Umwandlung von Silicium-Verbindungen: Enantioselektive Reduktion von Acetessigsäure(trimethylsilylalkyl)estern und deren CarbaAnaloga. Z Naturforsch 38b:616-620

Tacke R, Wuttke F, Zilch H, Andree H, Syldatk C, Wagner F, Ernst L, Schomburg D (1985) Enantioselective microbial reduction of racemic acetyl(t-butyl)methyl(phenyl)silane. Vth FECHEM Conference on Organometallic Chemistry, Riga 1985, Abstracts, p 188

Tacke R, Zilch H (1986a) Drug design by sila-substitution and microbial transformations of organosilicon compounds: Some recent results. L'Actualité Chimique (3):75-82

Tacke R, Zilch H (1986b) Sila-substitution - a useful strategy for drug design? Endeavour, New Series 10:191-197

Tacke R, Zilch H, Stumpf B, Ernst L, Schomburg D (1984) Microbiological transformation of organosilicon compounds: Enantioselective reduction of (dimethylsilyl)methyl acetoacetate and some cyclic and acyclic acyltriorganylsilanes. VIIth International Symposium on Organosilicon Chemistry, Kyoto 1984, Abstracts, p 201

Whitesides GM, Wong C-H (1985) Enzymes in organic synthesis. Angew Chem Int Ed Engl 24:617-638

Yonaha K, Soda K (1986) Applications of stereoselectivity of enzymes: Synthesis of optically active amino acids and $\alpha$ hydroxy acids, and stereospecific isotope-labeling of aminoacids, amines and coenzymes. Adv Biochem Eng Biotechnol 33:95-130

Zilch H, Tacke R (1986c) Fluorid-induzierte Fragmentierung von Acetyldimethylphenylsilan. J Organomet Chem $316: 243-247$

Received February 3, 1987/Revised May 22, 1987 